\title{
Active Learning Methodologies: An Experience for Faculty Training at Medical Education
}

\author{
Ieda Francischetti*, Camila Mugnai Vieira, Danielle Abdel Massih Pio, \\ Márcia Oliveira Mayo Soares, Ana Carolina Marques Colela, \\ Cássia Regina Rodrigues Nunes, Vera Lúcia Fedel Parpineli \\ Programa de Desenvolvimento Docente, Faculdade de Medicina de Marília (Famema), Marília, Brazil \\ Email: ${ }^{*}$ iedafster@googlemail.com
}

Received 10 September 2014; revised 8 October 2014; accepted 23 October 2014

Copyright (C) 2014 by authors and Scientific Research Publishing Inc.

This work is licensed under the Creative Commons Attribution International License (CC BY). http://creativecommons.org/licenses/by/4.0/

(c) (i) Open Access

\begin{abstract}
When studying the implementation movement of active learning methodologies, especially the Problem Based Learning (PBL) at medical schools, it is considered that faculty training is of great relevance and is a weakness to be overcome. In this paper, an experience from a medical school is shared concerning the accession to PBL especially focusing the course on the faculty development during this process. The Faculty Development Program (FDP), made permanent in this institution, is presented, as well as its steps in 17 years of existence: strategies and guidelines for practical support. At first, faculty training programs were based on Continuing Education (CE) and Permanent Education (PE) demonstrating theoretical references and methodologies paying greater attention to the current process of Academic Permanent Education (APE). This study also describes the APE organization, potentialities and weaknesses rates and, following that, broadens reflection on challenges surrounding faculty training programs in medical schools. It is concluded that APE, when promoting operative group activities and active knowledge production, it supports and strengthens team work. When stimulating active attitude for personal and professional teacher growth, APE also collaborates for pedagogical, curricular and humanistic development of the higher education institute.
\end{abstract}

\section{Keywords}

Faculty, Continuing Education, Medical Education, Undergraduate, Problem-Based Learning

\footnotetext{
"Corresponding author.
}

How to cite this paper: Francischetti, I., Vieira, C. M., Pio, D. A. M., Soares, M. O. M., Colela, A. C. M., Nunes, C. R. R., \& Parpineli, V. L. F. (2014). Active Learning Methodologies: An Experience for Faculty Training at Medical Education. Creative Education, 5, 1882-1886. http://dx.doi.org/10.4236/ce.2014.521210 


\section{Introduction}

In this paper is shared an innovative experience of a Brazilian medical school with implementation of active methods of learning in its course, especially focusing practice on faculty development within the process.

The Marilia Medical School was founded in 1967. It followed a traditional learning method based on transmitting and this way has been on its course for 30 years. When the Problem-Based-Learning was used in courses at universities such as McMaster, Maastricht and New Mexico it was more efficient to make students active in the learning process. They allowed the student to give a new meaning to knowledge from professional practice situations portrayed in paper problems; integrating subjects and different knowledge areas and inserted them through reality; at the same time guaranteed, in elective courses, space for specific interests (Barrows \& Tamblyn, 1980; Moust, Van Berkel, \& Schmidt, 2005).

PBL was implemented in Latin America only in the nineties. In Brazil it was a result of a global policy for health improvement and medical formation, considering initiatives from The World Health Organization (WHO) and the national policy for the Sanitary Reform consolidation - as an inducer and partner respectively, followed by a process of registering and selection of colleges.

Marilia Medical School started PBL implementation as a pedagogical instrument in 1997, based on its proved efficiency for promoting knowledge construction and high capacity to develop skills and affectivity of its students (Albanese \& Mitchell, 1993; Newman, 2003; Dochy, Segers, Van den Bossche, \& Struyven, 2005; Hoffman, Hosokawa, Blake, Headrick, \& Johnson, 2006).

During the method implementation and consolidation process, two large pedagogical movements were carried out: 1) teacher training, for the new teacher role, along with the global curriculum analysis; 2) curricular redesign in order to make easier different subjects and knowledge areas interactions (bio-psychosocial), making possible the necessary instruments for paper problems construction.

Considering teacher training to be of great relevance and at the same time a weakness to be overcome when establishing PBL at a medical school, as pointed out by Perim et al. (2009), the aim of this paper is to present the Faculty Development Program (FDP) implemented in this institution, its strategies and theoretical references, as well as support practical guidelines for its operation.

\section{Academic Permanent Education (APE) as a Driving Force of the Faculty Development}

FDP was started as a Continuing Education (CE) with sequenced offer of basic and advanced training to all teachers. Among the approached topics were: activities in small groups; active learning; the PBL seven steps; formative assessment; and skills in how to give and receive criticism. The CE activities took place in plenary sessions and small groups with the objective of stimulating reflection and insert teachers in labor logic in small groups (Francischetti et al., 2010).

For the past five years more than $90 \%$ of teachers have passed through these trainings, and they have been consistently included in curricular activities. When living PBL mediation reality in different course grades, other demands appeared and they made necessary a greater deepening in the training process, thus, the Academic Permanent Education (APE) was grown (Nunes, Rolin, \& Lopes, 2014).

The APE, which features longitudinal activity raging all units and grades, became a great driving force of the teacher development process, since it made it possible continuous and consistent elaboration of situations that raised from teacher practice. With pedagogical capacitation technology, APE was made out according to the theory of andragogy, based on Paulo Freire's critical and liberating education (Freire, 1999).

Implementation occurred in a procedural way, aiming meaningful learning (Ausubel, 1963 apud Moreira, 1997). This kind of learning is defined as a process by which new information or knowledge relates itself, in a substantial and non-arbitrary way, to the cognitive structure of the subject (Ausubel, 1963 apud Moreira, 1997). In order to occur, it is fundamental to consider the learner's background knowledge so that new concepts may be incorporated in a meaningful way. Affection and feelings are important for meaningful learning since it is necessary integration between thinking and action, meanings and feelings exchange among the object of study, the teacher and the student, which leads to human empowerment (Novak, Gowin, 1984 apud Moreira, 1997).

Among the uncountable possible strategies to be made to carry out APE, Problematization is used. Silva (2011), from reviews of Berbel (1998) and Bodernave and Pereira (1982), described the steps of Problematization as a process that comes from work practice, where, after task performing and a new experience, in a group 
session together with a mediator, participants discuss experiences and levels of difficulty and success in the socalled "experiential confront". From this reflection on, a provisional synthesis is made, with questionings. Later on, a theoretical search is made about those questionings and in the following session the group discusses, shares and builds knowledge and new understanding called "new synthesis", with reality applications.

Aiming meaningful learning and taking into account group particularity and context, some resources and strategies may be used to stimulate or support discussions, such as, small film or text passages, paper cases or problem-situations in order to make learning easier (Vieira, Soares, \& Locatelli, 2014).

During APE implementation it is interesting to emphasize activity planning, which includes group formation and how the participants are invited or summoned, for instance. There are several possibilities for group formation and criteria to be adopted, some groups are formed second the year of the course, area of operation, common group of students, or even mixed groups. It is important to guarantee that the sessions are determined under periods when everyone can take part (Vieira et al., 2014).

Sessions are used to occurring in small groups (6 to 8 participants), which provide people with more experience to be together with ones that do not have much of it, the talkative with the quiet, and together they stimulate one another and try to provide full participation so the objective may be reached. On the first session the "group contract" must be carried out, establishing the beginning and end of sessions, use of cell phones and other technology equipment, and also daily or periodic assessment, which includes self-assessment, as well as pair, activity and mediator ones (Vieira et al., 2014). Thus, assessment forms will be applied periodically, subsequently analyzed by the FDP group for diagnosing necessities and proposals for change (Faculdade de Medicina de Marília, 2008).

As a theoretical-technological reference which goes around group practice there are the fundamentals and operative group ideas of Pichon-Rivière (2009). Aim and purpose are summarized by saying that the activity is centered in the stereotyped structure mobilization due the amount of anxiety raised by the change. "On the operative group, the clarification, the communication, the learning and solved task coincide with cure, and then a new reference scheme is generated" (Bleger, Liberman, Pichon-Rivière, \& Rolla, 2009: p. 137). This type of group therefore, implies learning to think in terms of problem solving which appears in the group itself. It can appear from a participant who will be the spokesperson of him or herself and of the unconscious fantasies of the group, so the spokesperson will be interpreted at first followed by pointing out what has been presented, bearing in mind it is also about a group problem, and this is the different from the other techniques (Pichon-Rivière, 2009). This way, what the group communicates on each session is worked out inside the group dynamics and the resonance phenomenon described by Zimerman (2007) occurs, many times exemplified by one of the professor's experiences which resounds to another member of the group, who transmits equivalent meaning (Pio \& Angeli, 2014). In the group, affective interaction among professors makes fantasies, anxiety, defense mechanisms and transference and contra-transference phenomena come out and that generates a dynamic group area (Zimerman, 2007).

Thus, when APE institutionalizes active knowledge production by its participants, can ameliorate the works groups and relationships that permeate this rich relational conformation supporting and making teamwork easy. The greatest effort is focusing attention on the subjects and their interactions, for performing the proposals to be carried out by the group. In order to have suitable mediation and observation of both relational and pedagogical-assistance aspects in question, APE counts on two facilitators. The choice of a professional from mental health as a mediator allows better work with group conflicts and operative group techniques, permitting theoretical foundation and quality of APE activities (Gomes, Francischetti, \& Parpinelli, 2014).

This way, APE tends to work as a dialogue space for experience exchange and meta-critical evaluation concerning professional practice. Reflection is fostered, with opportunity for discovering new personal resources and competence development to teach health under a new training approach (Pio \& Angeli, 2014).

It is understood that practice transformation and multiplier formation go through the subjects (group participants), who must bring true motivation for development and desire to carry out a recognized good job. Therefore it is a more political and humanistic approach, hoping to promote citizenship (Gomes et al., 2014).

The results are continuous and perennial, and many times a little slow. Facilitators who go through several teaching-learning scenarios become strong reference among different teaching segments and take part in building this new paradigm; because either as facilitators or professors, they acquire broad view of this construction and contribute to the development of APE work groups (Gomes et al., 2014).

However, in literature several obstacles are identified: a) doctor's interest lack on pedagogical knowledge; b) 
exaggerated technical-scientific knowledge valorization; c) fragile employment link professor-institution; d) incompatibility between the professional profile and the course demands (Costa, 2010; Moust, Van Berkel, \& Schmidt, 2005).

On the faculty established before the pedagogical innovation is the ones who were not included and the ones who did not let to be included, and the possible causes might be: centered management and conservative professors. Isolation may become a barrier. However, when using effective communication, the manager may promote experience exchange among professors, include them, and allow their engagement in the process (Zeichner, 2008).

\section{Conclusion}

In the newer medical schools, selection processes have been made for a professional profile oriented for: professors with pedagogical experience who work as facilitators, who work on his or her own formation, and who work on curricular construction (Machado, Machado, \& Vieira, 2011).

It would be harmful for school image to abandon the old professors and to invest only in new hiring. It is necessary, for pedagogical change, that all teachers: new, old, from initials to those of final course years, should be included in the permanent education process. It is believed that the pedagogical development must pass through socialization of different ideas to transform the institutional culture and curriculum. These are only possible with the valorization of all faculties by the institution and commitment of each teacher.

Many institutions offer CE and do it inconstantly most of the times, and only for first-year professors. There are those that promote multiplier oriented training sessions. The promotion of multiplier is helpful but does not displace the individual professor training.

In Brazil, a study showed that a few schools can promote long-lasting programs and Permanent Education (PE) (Almeida, Maia, \& Batista, 2013). Among them are the ones by Marilia Medical School with systematized practice and assured by continuous programs for their participants, and those with non-systematized practice in continuous programs (Faria, Nunes, Anastasiou, Sakai, \& Silva, 2008; Francischetti et al., 2014).

It is thought that small-group-based practices provided by APE ensure further development of skills for the following student group activities. Its systematic approach enables better monitoring and assessment of the process and the performance of each participant. The non-systematized practice is weak to built pedagogical framework to support the learning tension that exists at the theory-practice and knowledge-behavior integrations, in a new care model.

\section{References}

Albanese, M. A., \& Mitchell, S. (1993). Problem-Based Learning: A Review of the Literature on Its Outcomes and Implementation Issues. Academic Medicine, 68, 52-81. http://dx.doi.org/10.1097/00001888-199301000-00012

Almeida, M. T. C., Maia, F. A., \& Batista, N. A. (2013). Gestão nas escolas médicas e sustentabilidade dos programas de desenvolvimento docente. Avaliação, 18, 299-310. http://dx.doi.org/10.1590/S1414-40772013000200004

Barrows, H. S., \& Tamblyn, R. M. (1980). Problem-Based Learning: An Approach to Medical Education. New York, NY: Springer.

Berbel, N. A. N. (1998). A problematização e a aprendizagem baseada em problemas. Interface: Comunicação, Saúde, Educação, 2, 139-154. http://dx.doi.org/10.1590/S1414-32831998000100008

Bleger, J., Liberman, D., Pichon-Rivière, E., \& Rolla, E. (2009). Técnica dos grupos operativos. In E. Pichon-Rivière (Ed.), O processo grupal (8a ed., pp. 121-137). São Paulo: Editora Martins Fontes.

Bodernave, J. D., \& Pereira, A. M. (1982). Estratégias de ensino-aprendizagem. Petrópolis: Vozes.

Costa, N. M. S. C. (2010) Pedagogical Training of Medicine Professors. Revista Latino-Americana de Enfermagem, 18, 102108. http://dx.doi.org/10.1590/S0104-11692010000100016

Dochy, F., Segers, M., Van den Bossche, P., \& Struyven, K. (2005). Student's Perceptions of a Problem-Based Learning Environment. Learning Environments Research, 8, 41-66. http://dx.doi.org/10.1007/s10984-005-7948-x

Faculdade de Medicina de Marília (2008). Caderno do programa de desenvolvimento docente: Cursos de Medicina e Enfermagem. Marília: Faculdade de Medicina de Marília.

Faria, M. J. S. S., Nunes, E. F. P. A., Anastasiou, L., Sakai, M. H., \& Silva, V. L. M. (2008). The Challenge of Faculty Development: The Experience of the Medical School at the State University of Londrina. Revista Brasileira de Educação Médica, 32, 248-253. http://dx.doi.org/10.1590/S0100-55022008000200013 
Francischetti, I. et al. (2010). Programa de desenvolvimento docente (PDD) da Faculdade de Medicina de Marília (Famema): Estratégia reflexiva para a transformação das práticas. In Congresso Internacional PBL. http://www.each.usp.br/pbl2010/trabs/trabalhos/R0214-1.pdf

Freire, P. (1999). Pedagogia da autonomia: saberes necessários à prática educativa (2a ed.). Rio de Janeiro: Paz e Terra.

Gomes, C. P. M. L., Francischetti, I., \& Parpineli, V. L. F. (2014). Educação permanente na academia (EPA) e educação permanente em saúde (EPS): confluências. In Francischetti et al. (Orgs.), Educação permanente na academia: Da teoria à prática (pp. 29-36). Curitiba: CRV.

Hoffman, K., Hosokawa, M., Blake Jr., R., Headrick, L., \& Johnson, G. (2006). Problem-Based Learning Outcomes: Ten Years of Experience at the University of Missouri-Columbia School of Medicine. Academic Medicine, 81, 617-625. http://dx.doi.org/10.1097/01.ACM.0000232411.97399.c6

Machado, J. M., Machado, V. M., \& Vieira, J. E. (2011). Faculty Recruitment and Development for Innovative Curricula in Undergraduate Health Courses. Revista Brasileira de Educação Médica, 35, 326-333. http://dx.doi.org/10.1590/S0100-55022011000300005

Moreira, M. A. (1997). Aprendizagem significativa crítica. In M. A. Moreira, M. L. R. Palmero, \& M. C. C. Sahelices (Coords.), Aprendizagém significativa: Um conceito subjacente. In LaSalle-Centro Universitario, Encuentro Internacional sobre el Aprendizaje Significativo (pp. 33-45). Burgos: Universidad de Burgos.

http://www.if.ufrgs.br/ moreira/apsigcritport.pdf

Moust, J. H. C., Van Berkel, H. J. M., \& Schmidt, H. G. (2005). Reflections on Three Decades of Problem-Based Learning. Higher Education, 50, 665-683. http://dx.doi.org/10.1007/s10734-004-6371-z

Newman, M. (2003). A Pilot Systematic Review and Meta-Analysis on the Effectiveness of Problem Based Learning. Campbell Collaboration Systematic Review Group on the Effectiveness of Problem Based Learning. Newcastle, UK: University of Newcastle; Learning and Teaching Support Network.

Nunes, C. R. R., Rolin, L. M. G., \& Lopes, V. M. M. (2014). Os primórdios da educação permanente na academia e nos serviços de saúde. In Francischetti et al. (Orgs.), Educação Permanente na Academia: Da teoria à prática (pp. 17-28). Curitiba: CRV.

Perim, G. L., Abdalla, I. G., da Silva, R. H. A., Lampert, J. B., Stella, R. C. R., \& Costa, N. M. S. C. (2009). Teaching Developmentand Medical Education. Revista Brasileira de Educação Médica, 33, 70-82. http://dx.doi.org/10.1590/S0100-55022009000500008

Pichon-Rivière, E. (2009) O Processo Grupal (8a ed.). São Paulo: Editora Martins Fontes.

Pio, D. A. M., \& Angeli, O. A. (2014). Integração do processo grupal com o processo de ensino-aprendizagem: Experiência com grupos de educação permanente na academia (EPA). In I. Francischetti et al. (Eds.), Educação permanente na academia: Teoria e prática (pp. 49-55). Curitiba: CRV.

Silva, R. H. A., \& Scapin. L. T. (2011). Utilização da avaliação formativa para a implementação da problematização como método ativo de ensino-aprendizagem. Estudos em Avaliação Educacionais, 22, 537-552.

Vieira, C. M., Soares, M. O. M., \& Locatelli, R. R. (2014). Educação permanente na academia (EPA): Fundamentos, planejamento e estratégias. In: Francischetti et al. (Orgs.), Educação permanente na academia: da teoria à prática (pp. 37-48). Curitiba: CRV.

Zeichner, K. M. (2008). A Critical Analysis of Reflection as a Goal for Teacher Education. Educação \& Sociedade, 29, 535554. http://dx.doi.org/10.1590/S0101-73302008000200012

Zimerman, D. E. (2007). A importância dos grupos na saúde, cultura e diversidade. Vínculo, 4, 1-16. 
Scientific Research Publishing (SCIRP) is one of the largest Open Access journal publishers. It is currently publishing more than 200 open access, online, peer-reviewed journals covering a wide range of academic disciplines. SCIRP serves the worldwide academic communities and contributes to the progress and application of science with its publication.

Other selected journals from SCIRP are listed as below. Submit your manuscript to us via either submit@scirp.org or Online Submission Portal.
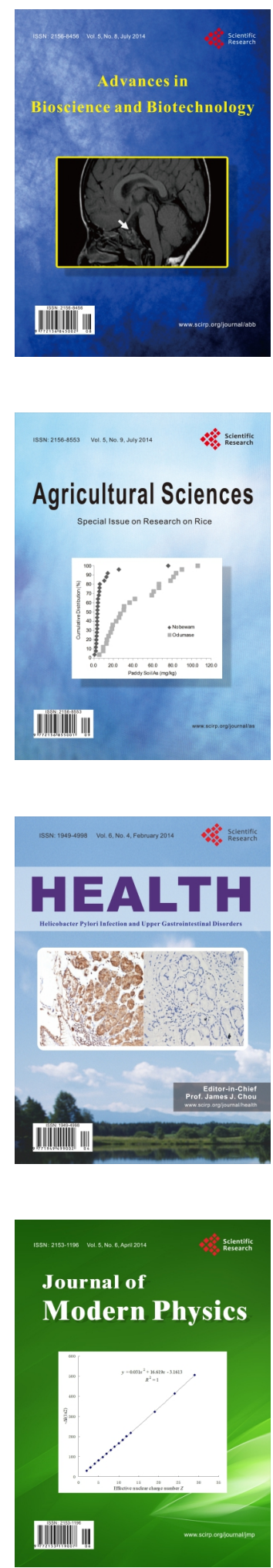
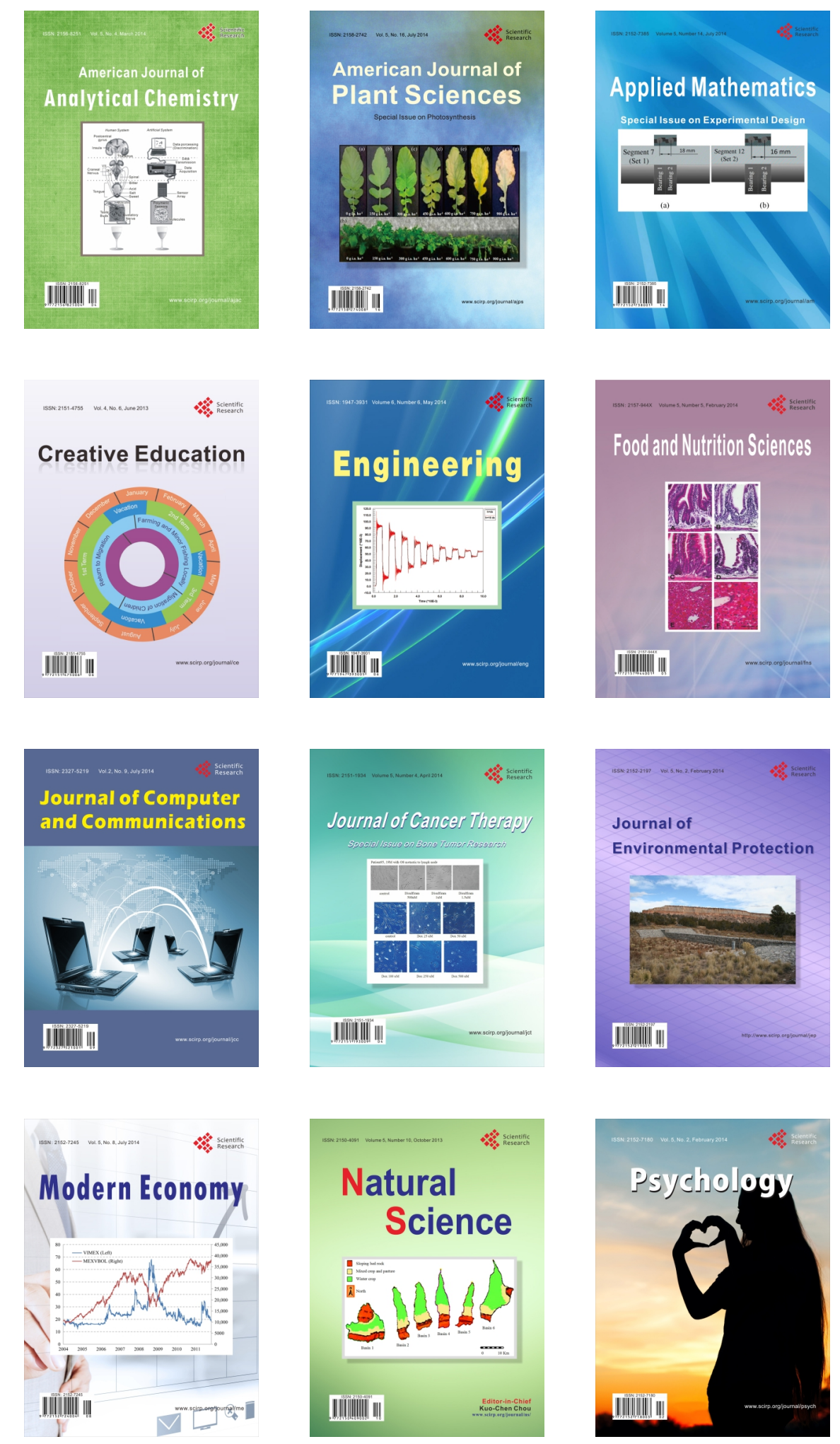